\begin{tabular}{|c|c|}
\hline \multirow{3}{*}{ 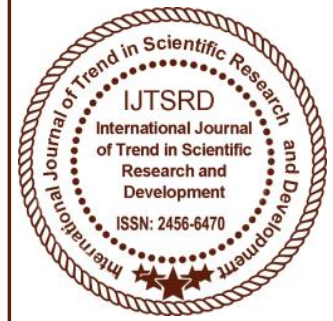 } & $\begin{array}{l}\text { International Journal of Trend in Scientific } \\
\text { Research and Development (IJTSRD) }\end{array}$ \\
\hline & International Open Access Journal \\
\hline & ISSN No: 2456 - 6470 | www.ijtsrd.com | Volume - 2 | Issue - 5 \\
\hline
\end{tabular}

\title{
Comparative Study on Effect of Fly Ash and Rice Husk Ash on Strength of Concrete
}

\author{
Mir Fairoz Akhter', Faiyaz Azam², Dr. Asif Hussain ${ }^{3}$ \\ ${ }^{1}$ Student, ${ }^{2}$ Assistant Professor, ${ }^{3}$ Professor \\ 1,2,3 Department of Civil Engineering, \\ ${ }^{1,2} \mathrm{Al}$-falah University, Dhauj, Faridabad, Haryana, India, ${ }^{3}$ Jamia Millia Islamia, New Delhi, India
}

\begin{abstract}
The construction of concrete pavement is growing across the country due to its strength, durability, better serviceability \& overall economy in long run. The need is to develop better quality pavement sections, which can bear heavy loads. This can be achieved by using high compressive strength concrete $(>40 \mathrm{MPa})$ made up of hydraulic cement having fine $\&$ course aggregates. In the work embodied construction work is done with the help of wastage from industry. Fly ash is a by-product of burned coal from thermal plants and Rice husk ash is the by-product of burned rice husk from paper plant. Considerably Fly ash and Rice husk ash are used as supplementary cementing materials to improve the properties of cement concrete.
\end{abstract}

The present study is done to develop pavement quality concrete by partially replacement cement with Fly Ash \& Rice Husk Ash. The aim of study is to compare the strength characterises of pavement concrete which as achieved by concrete mixtures. The work done in this study shows the effects on the behaviour of concrete produced from cement with combination of FA and RHA at different proportions on the mechanical properties of concrete such as compressive strength, flexural strength. The replacement of cement were done at three levels is $10 \%, 20 \%$ and $30 \%$ with both Fly ash \& Rice husk ash as well as combination of both Fly ash and Rice husk ash. The tests on hardened concrete were destructive in nature which includes compressive test on cube for size $(150 \times 150 \times 150 \mathrm{~mm})$ at 7 and 28 days of curing as per IS: 516 1959, Flexural strength on beam $(150 \times 150 \times 700 \mathrm{~mm})$ at 28 days of curing as per IS: 516 1959. The samples were prepared with different water-cement ratio as $0.30,0.35 \& 0.40$ for flexure design i.e. 5.5 MPa, 5.0 $\mathrm{MPa} \& 4.5 \mathrm{MPa}$ respectively. The result so obtained showed that it is possible to achieve saving in cement if replacement is done. The study proves to be beneficial in area where traffic load is less, also will use wastage released from thermal plants \& rice mills also reduces economy as this materials is easily available. The waste material from industries is in bulk amount, as lesser amount of these used as supplementary cementing materials so these can be used as filling soil in subgrade of highway pavement

Keyword: Rice Husk Ash, Aggregates, Fibers

\subsection{INTRODUCTION}

Concrete is a composite material composed mainly of water, aggregate, and cement. Often, additives and reinforcements are included in the mixture to achieve the desired physical properties of the finished material. When these ingredients are mixed together, they form a fluid mass that is easily molded into shape.

Concrete is widely used for making architectural structures, foundations, brick/block walls, pavements, bridges/overpasses, highways, runways, parking structures, dams, pools/reservoirs, pipes, footings for gates, fences and poles and even boats. Concrete is used in large quantities almost everywhere mankind has a need for infrastructure. 
The amount of concrete used worldwide, ton for ton, is twice that of steel, wood, plastics, and aluminum combined. Concrete's use in the modern world is exceeded only by that of naturally occurring water.

There are many types of concrete available, created by varying the proportions of the main ingredients below. In this way or by substitution for the cementations and aggregate phases, the finished product can be tailored to its application with varying strength, density, or chemical and thermal resistance properties [RS 2003].

From 1880 to 1996 , the world's annual consumption of Portland cement rose from 2 million tons to 1.3billion tons. This was associated with major environmental cost include: a) cement manufacturing is the third2 2 largest CO producer and for over 50\% of all industrial $\mathrm{CO}$ emissions (for every 1ton of cement produced,.25 ton of $\mathrm{CO}$ is released in the air); b) 1.6 ton of natural resources is consumed to produce 1 ton of cement(Muga, H., K. Betz, 2005). This calls for the use of sustainable binders. One of the most promising materialsis the rice husk ash (RHA).

Rice husk is an agricultural residue from the rice FAO(2008), the annual world rice production for 2007 was estimated by 649.7 million tons, the Husk constitute approximately $20 \%$ of it. The chemical composition of Rice Husk is found to vary from sample to another dueto the differences in the type of paddy, crop year, climate and geographical conditions (Chandrasekhar, S., S. K. G. Pramada, 2003). Burning the husk under controlled temperature below $800<$ can produce ash with silicamainly in amorphous form (Chandrasekhar, S., S.K.G. Pramada, 2003; Zhang, M.H., V.M. Malhotra, 1996). milling process. According to the United Nations

research findings from several countries on the use of RHA as a supplementary cementing Pozzolanic material. Pozzolan- a siliceous or alumino-siliceous material that in itself possesses little or no Cementitious value but that in finely divided form and in the presence of moisture will chemically react with alkali and alkaline earth hydroxides at ordinary temperatures to form or assist in forming compounds possessing cementitious properties (ASTM, 1995). So far, according to the author's literature, RHA has not been utilized yet in the construction industry, except for some repairing works in the US where it was used in a dry-mix shotcrete to repair the Bowman Dam in northern California's Sierra Nevada Mountains, with positive results (Talend, D., 1997). The reason for not utilising this material may be probably due to lack of understanding of the RHA blended concrete characteristics. Many researchers have already published on the properties of the blended RHA concrete such as strength and durability. However, only few researches were found on the effect of RHA Average Particle Size (APS) on the properties of concrete.

\subsection{OBJECTIVES}

The objectives and scope of present study are

To study the relative strength development of [RHA, FA, (RHA+FA)] concrete.

Use of industrial waste in a useful manner.

$>$ To conduct Compression Test on [RHA, FA, (RHA+FA)] concrete on standard IS specimen size $(150 X 150 X 150) \mathrm{mm}$.

$>$ To conduct Flexural Test on [RHA, FA, $(\mathrm{RHA}+\mathrm{FA})]$ and concrete on standard IS specimen size $(150 \mathrm{X} 150 \mathrm{X} 700) \mathrm{mm}$.

To provide economical construction material.

Provide safeguard to the environment by utilizing waste properly.

A state-of-the-art report on rice husk ash (RHA) was published by Mehta 1992, and contains a review of physical and chemical properties of RHA, the effect of incineration conditions on the Pozzolanic characteristics of the ash, and a summary of the

\subsection{RICE HUSK ASH}

Completely burnt rice husk ash was brought from rice mills from Rajpura. Its physical and chemical properties are given in Table 3.9 and Table 3.10 respectively [RK 2013].

Table 1.1 Physical properties of rice husk ash

\begin{tabular}{|l|c|}
\hline Physical property & Value \\
\hline Colour & gray with slight black \\
\hline Bulk density & $104.9 \mathrm{~kg} / \mathrm{m}^{3}$ \\
\hline Specific gravity & 1.96 \\
\hline Fineness & $2775 \mathrm{~cm}^{2} / \mathrm{gm}$ \\
\hline Avg particle size & $150.47 \mu \mathrm{m}$ \\
\hline Mesopores & $78 \%$ \\
\hline Heating value & $9.68 \mathrm{MJ} / \mathrm{kg}$ \\
\hline
\end{tabular}


International Journal of Trend in Scientific Research and Development (IJTSRD) ISSN: 2456-6470

Table 1.2 Chemical properties of rice husk ash

\begin{tabular}{|l|c|}
\hline Component & $\mathbf{\%}$ \\
\hline Silica & 92.1 \\
\hline Alumina & 0.51 \\
\hline Iron oxide & 0.40 \\
\hline Calcium oxide & 0.55 \\
\hline Potassium oxide & 1.53 \\
\hline Titanium di oxide & 0.02 \\
\hline Manganese oxide & 0.08 \\
\hline Phosphorous penta oxide & 0.08 \\
\hline Sulphur tri oxide & 0.12 \\
\hline
\end{tabular}

\subsection{RESULTS AND DISCUSSIONS:}

\subsubsection{Overview}

The study was undertaken to investigate the compressive strength and flexural strength of concrete with different levels of replacement of cement with fly ash and rice husk ash in concrete mix. Cement was partially replaced by fly ash at three different levels of replacement i.e. $10 \%, 20 \%$ and $30 \%$ and same with rice husk ash. Concrete mixtures were also cast with combined replacements of fly ash and rice husk ash. Tests were performed after 7 and 28 days of curing of concrete. Cubes and beams were prepared for determining compressive strength and flexural strength of concrete with different water-cement ratio as $0.30,0.35$ and 0.40 for minimum required flexural strengths of $5.5 \mathrm{~N} / \mathrm{mm} 2 \quad 5 \mathrm{~N} / \mathrm{mm} 2 \quad 4.5 \mathrm{~N} / \mathrm{mm} 2$, respectively. Super-plasticizer was used in all the mixes at $1 \%$ level by weight of cementitious material.

\subsubsection{Compressive Strength}

It is the most common test conducted on hardened concrete as it is an easy test to perform and also most of the desirable characteristic properties of concrete are qualitatively related to its compressive strength. The compression test is carried out on specimens cubical in shape of the size $150 \times 150 \times 150 \mathrm{~mm}$. The test is carried out in the following steps: First of all, the mould preferably of cast iron, is used to prepare the specimen of size $150 \times 150 \times 150 \mathrm{~mm}$. During the placing of concrete in the mounds it is compacted with the tamping bar with not less than 35 strokes per layer. Then these mounds are placed on the vibrating table and are compacted until the maximum possible compaction is attained. After 24 hours, the specimens are removed from the mounds and immediately submerged in clean fresh water. The specimens can be

tested at the end if 7,14 and 28 days in compression testing machine.

\subsubsection{General}

In most structural applications, concrete is employed primarily to resist compressive stresses. When a plain concrete member is subjected to compression, the failure of the member takes place, in its vertical plane along the diagonal. The vertical crack occurs due to lateral tensile strains. A flow in the concrete, which is in the form of micro crack along the vertical axis of the member will take place on the application of axial compression load and propagate further due to the lateral tensile strains.

\subsubsection{Test Procedure and Results}

Test specimens of size $150 \mathrm{~mm} \times 150 \mathrm{~mm} \times 150 \mathrm{~mm}$ were prepared for testing the compressive strength (FR00, FR10 \& FR20 etc.). The mix was done manually. The cement and fine aggregate were first mixed dry to uniform colour and then coarse aggregate was added and mixed with the mixture of cement and fine aggregates. Water was then added and the whole mass mixed. The interior surface of the moulds and the base plate were highly oiled before concrete was placed. After this the specimens were removed from the moulds and placed in clean fresh water at for 28 days curing. For testing in compression, no cushioning material was placed between the specimen and the plates of the machine. The load was applied axially without shock till the specimen was crushed. Test results of compressive strength test at the age of 7 days \& 28 days are given in the Table 2.1, Table 2.2 and Table 2.3 respectively. 
International Journal of Trend in Scientific Research and Development (IJTSRD) ISSN: 2456-6470

Table 2.1 Compressive strength $(\mathrm{w} / \mathrm{c}=\mathbf{0 . 4})$

\begin{tabular}{|c|c|c|c|c|}
\hline \multirow[b]{2}{*}{$\mathrm{w} / \mathrm{c}=0.4$} & \multicolumn{2}{|c|}{7 Days } & \multicolumn{2}{|c|}{28 Days } \\
\hline & $\begin{array}{c}\text { Avg. Load } \\
\text { (KN) }\end{array}$ & $\begin{array}{c}\mathbf{f}_{\mathrm{c}} \\
\left(\mathrm{N} / \mathbf{m m}^{2}\right)\end{array}$ & $\begin{array}{c}\text { Avg. Load } \\
\text { (KN) }\end{array}$ & $\begin{array}{c}\mathbf{f}_{\mathbf{c}} \\
\left(\mathrm{N} / \mathbf{m m}^{2}\right)\end{array}$ \\
\hline $\begin{array}{c}\text { Controlled } \\
\text { (FRo0) }\end{array}$ & 855.03 & 37.92 & 1142.66 & 51.22 \\
\hline $\begin{array}{c}10 \% \text { F.A. } \\
\text { (FR10) }\end{array}$ & 843.63 & 37.54 & 1096.33 & 47.84 \\
\hline $\begin{array}{c}20 \% \text { F.A. } \\
\text { (FR20) }\end{array}$ & 768.633 & 34.4524 & 1011.1 & 45.36 \\
\hline $\begin{array}{c}30 \% \text { F.A. } \\
\text { (FR30) }\end{array}$ & 652.366 & 28.3268 & 931.133 & 40.9826 \\
\hline $\begin{array}{c}10 \% \text { R.H.A. } \\
\text { (FR01) }\end{array}$ & 503.97 & 22.55 & 729.36 & 32.44 \\
\hline $\begin{array}{c}20 \% \text { R.H.A } \\
\text { (FR02) }\end{array}$ & 435.9 & 19.7522 & 641.133 & 28.4137 \\
\hline $\begin{array}{c}\text { 30\% R.H.A. } \\
\text { (FR03) }\end{array}$ & 363.2 & 15.8511 & 570.9 & 24.8955 \\
\hline $\begin{array}{c}10 \% \text { F.A. } \\
10 \% \text { R.H.A. } \\
\text { (FR11) }\end{array}$ & 468.2 & 20.7677 & 722.933 & 31.7525 \\
\hline $\begin{array}{c}20 \% \text { F.A. } \\
10 \% \text { R.H.A } \\
\text { (FR21) }\end{array}$ & 365.17 & 16.45 & 615.3 & 26.9688 \\
\hline $\begin{array}{c}10 \% \text { F.A } \\
20 \% \text { R.H.A. } \\
\text { (FR12) }\end{array}$ & 354.63 & 15.47 & 577.56 & 25.79 \\
\hline
\end{tabular}

$*_{c}=$ Compressive strength

$F R=$ Mould No.

$F . A=F l y$ Ash

R.H.A. = Rice Husk Ash

Table 2.2 Compressive strength $(\mathrm{W} / \mathrm{C}=\mathbf{0 . 3 5})$

\begin{tabular}{|c|c|c|c|c|}
\hline \multirow[b]{2}{*}{$w / c=0.35$} & \multicolumn{2}{|c|}{7 Days } & \multicolumn{2}{|c|}{28 Days } \\
\hline & $\begin{array}{l}\text { Avg Load } \\
\text { (KN) }\end{array}$ & $\begin{array}{c}f_{\mathrm{c}} \\
\left(\mathrm{N} / \mathrm{mm}^{2}\right)\end{array}$ & $\begin{array}{l}\text { Avg Load } \\
\text { (KN) }\end{array}$ & $\begin{array}{c}\mathbf{f}_{\mathrm{c}} \\
\left(\mathrm{N} / \mathrm{mm}^{2}\right)\end{array}$ \\
\hline $\begin{array}{l}\text { Controlled } \\
\text { (FR00) }\end{array}$ & 920.5 & 40.712 & 1279.66 & 55.764 \\
\hline $\begin{array}{c}10 \% \text { F.A. } \\
\text { (FRl0) }\end{array}$ & 850.933 & 37.519 & 1120 & 48.68 \\
\hline $\begin{array}{c}20 \% \text { F.A. } \\
\text { (FR20) }\end{array}$ & 791.666 & 34.175 & 1083.33 & 48.548 \\
\hline $\begin{array}{c}30 \% \text { F.A. } \\
\text { (FR30) }\end{array}$ & 734.466 & 32.142 & 963.3 & 41.713 \\
\hline $\begin{array}{c}\text { 10\% R.H.A. } \\
\text { (FR01) }\end{array}$ & 543.86 & 24.77 & 758.56 & 32.71 \\
\hline $\begin{array}{c}20 \% \text { R.H.A } \\
\text { (FR02) }\end{array}$ & 486.833 & 21.547 & 712.633 & 30.762 \\
\hline $\begin{array}{c}\text { 30\% R.H.A. } \\
\text { (FR03) }\end{array}$ & 435.533 & 18.258 & 604.166 & 25.841 \\
\hline $\begin{array}{c}10 \% \text { F.A. } \\
10 \% \text { R.H.A. } \\
\text { (FRll) }\end{array}$ & 537.766 & 22.758 & 786.633 & 34.661 \\
\hline $\begin{array}{c}20 \% \text { F.A. } \\
10 \% \text { R.H.A } \\
\text { (FR21) }\end{array}$ & 470.133 & 20.1948 & 724.833 & 31.214 \\
\hline $\begin{array}{c}10 \% \text { F.A } \\
20 \% \text { R.H.A. } \\
\text { (FR12) }\end{array}$ & 411.233 & 17.274 & 685.5 & 29.45 \\
\hline
\end{tabular}

$* f c=$ Compressive strength

$F R=$ Mould No.

F.A = Fly Ash

R.H.A. = Rice Husk Ash 
International Journal of Trend in Scientific Research and Development (IJTSRD) ISSN: 2456-6470

Table 2.3 Compressive strength $(\mathrm{W} / \mathrm{C}=\mathbf{0 . 3})$

\begin{tabular}{|c|c|c|c|c|}
\hline \multirow[b]{2}{*}{$\mathrm{w} / \mathrm{c}=0.30$} & \multicolumn{2}{|c|}{7 Days } & \multicolumn{2}{|c|}{28 Days } \\
\hline & $\begin{array}{l}\text { Avg Load } \\
\text { (KN) }\end{array}$ & $\begin{array}{c}\mathbf{f}_{\mathrm{c}} \\
\left(\mathrm{N} / \mathrm{mm}^{2}\right)\end{array}$ & $\begin{array}{l}\text { Avg Load } \\
\text { (KN) }\end{array}$ & $\begin{array}{c}f_{\mathrm{c}} \\
\left(\mathrm{N} / \mathrm{mm}^{2}\right)\end{array}$ \\
\hline $\begin{array}{c}\text { Controlled } \\
\text { (FR00) }\end{array}$ & 1047.66 & 45.4562 & 1388 & 60.6778 \\
\hline $\begin{array}{c}10 \% \text { F.A. } \\
\text { (FRl0) }\end{array}$ & 954.433 & 41.4092 & 1199.33 & 52.2374 \\
\hline $\begin{array}{c}20 \% \text { F.A. } \\
\text { (FR20) }\end{array}$ & 999.8 & 43.4455 & 1193.66 & 52.0518 \\
\hline $\begin{array}{r}30 \% \text { F.A. } \\
\text { (FR30) }\end{array}$ & 738.233 & 31.8102 & 1039.73 & 45.2104 \\
\hline $\begin{array}{c}\text { 10\% RH.A. } \\
\text { (FR01) }\end{array}$ & 601.67 & 25.74 & 995.67 & 43.25 \\
\hline $\begin{array}{c}20 \% \text { R.H.A } \\
\text { (FR02) }\end{array}$ & 526.73 & 22.45 & 725.7 & 32.8583 \\
\hline $\begin{array}{c}30 \% \text { RH.A. } \\
\text { (FR03) }\end{array}$ & 480.2 & 20.3421 & 609.8 & 26.102 \\
\hline $\begin{array}{c}10 \% \text { F.A. } \\
\text { 10\%R.H.A. } \\
\text { (FRll) }\end{array}$ & 739.566 & 30.87 & 938.667 & 43.7 \\
\hline $\begin{array}{c}20 \% \text { F.A. } \\
10 \% \text { R.H.A } \\
\text { (FR2l) }\end{array}$ & 582.333 & 24.97 & 850.933 & 37.57 \\
\hline $\begin{array}{c}10 \% \text { F.A } \\
20 \% \text { R.H.A. } \\
\text { (FRl2) }\end{array}$ & 482.03 & 21.24 & 786.633 & 34.89 \\
\hline
\end{tabular}

$* \mathrm{fc}=$ Compressive strength

FR = Mould No.

F.A = Fly Ash

R.H.A. = Rice Husk Ash

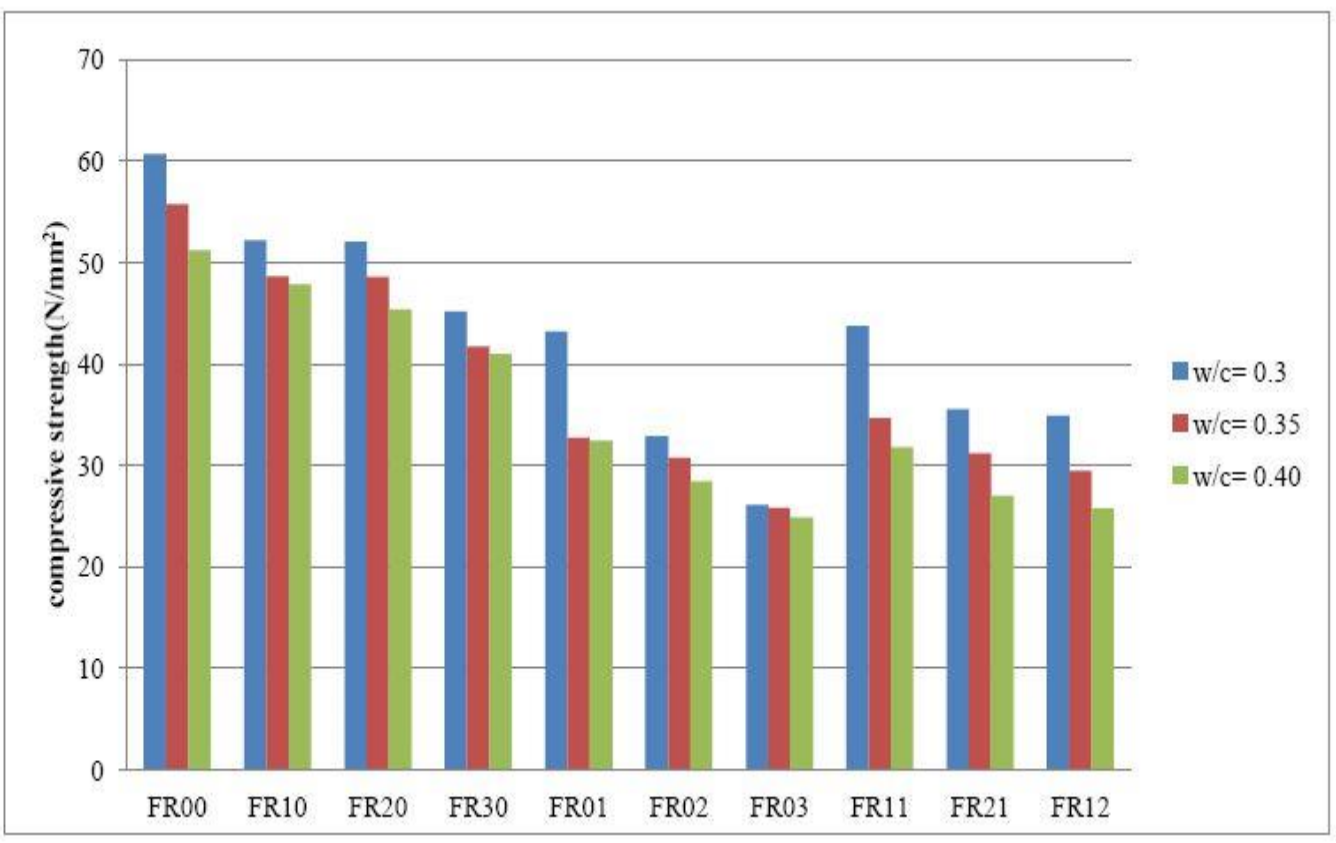

Fig 2.1: 28-day compressive strengths for all water cement ratios 


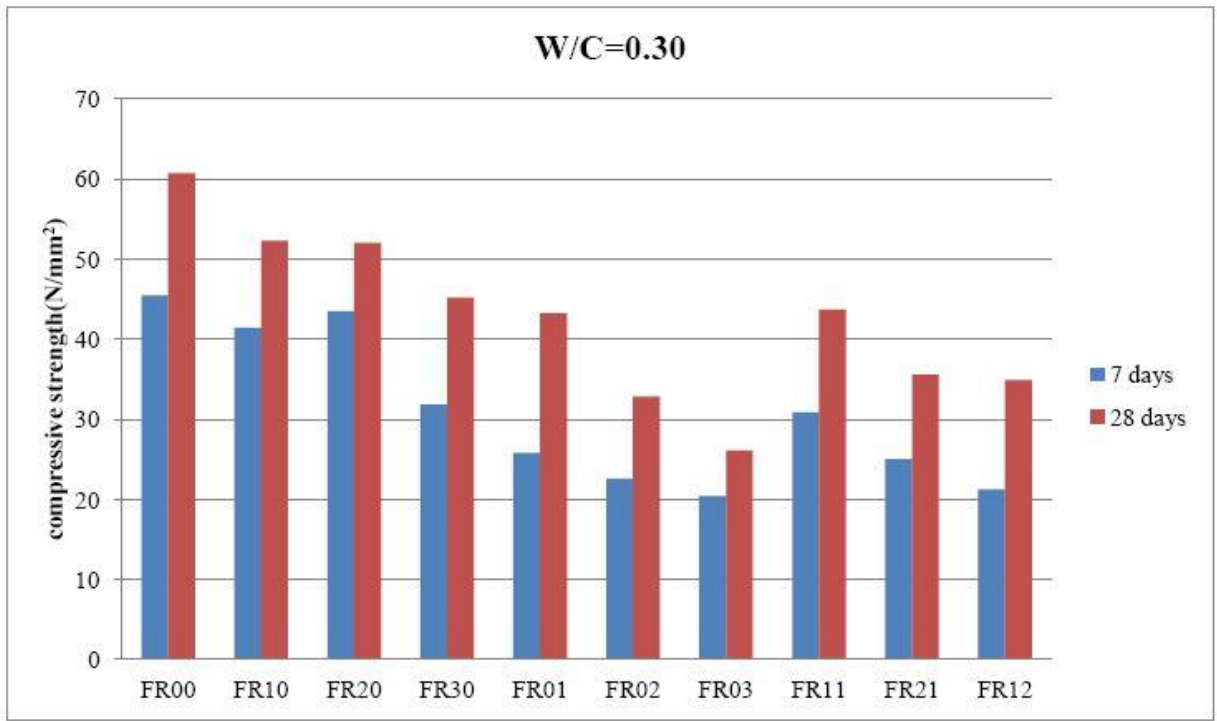

Fig 2.2: 7-day and 28-day compressive strengths with w/c $=0.30$

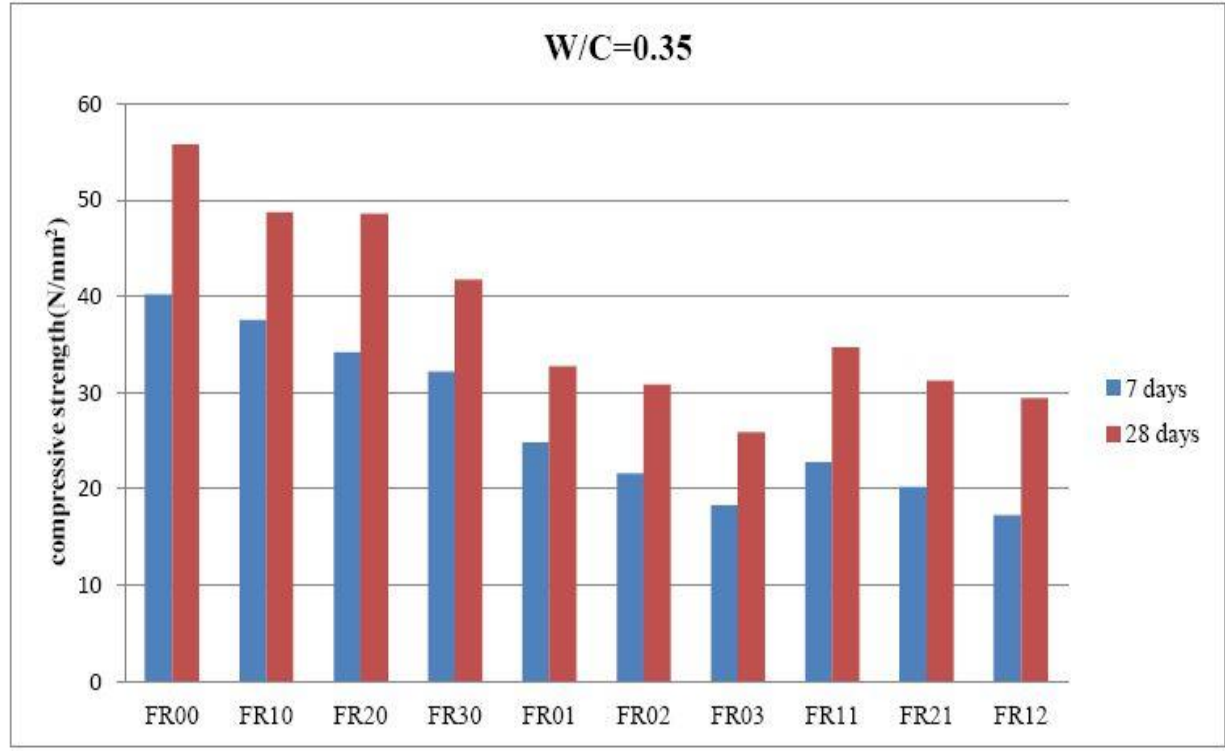

Fig 2.3: 7-day and 28-day compressive strengths with w/c $=0.35$

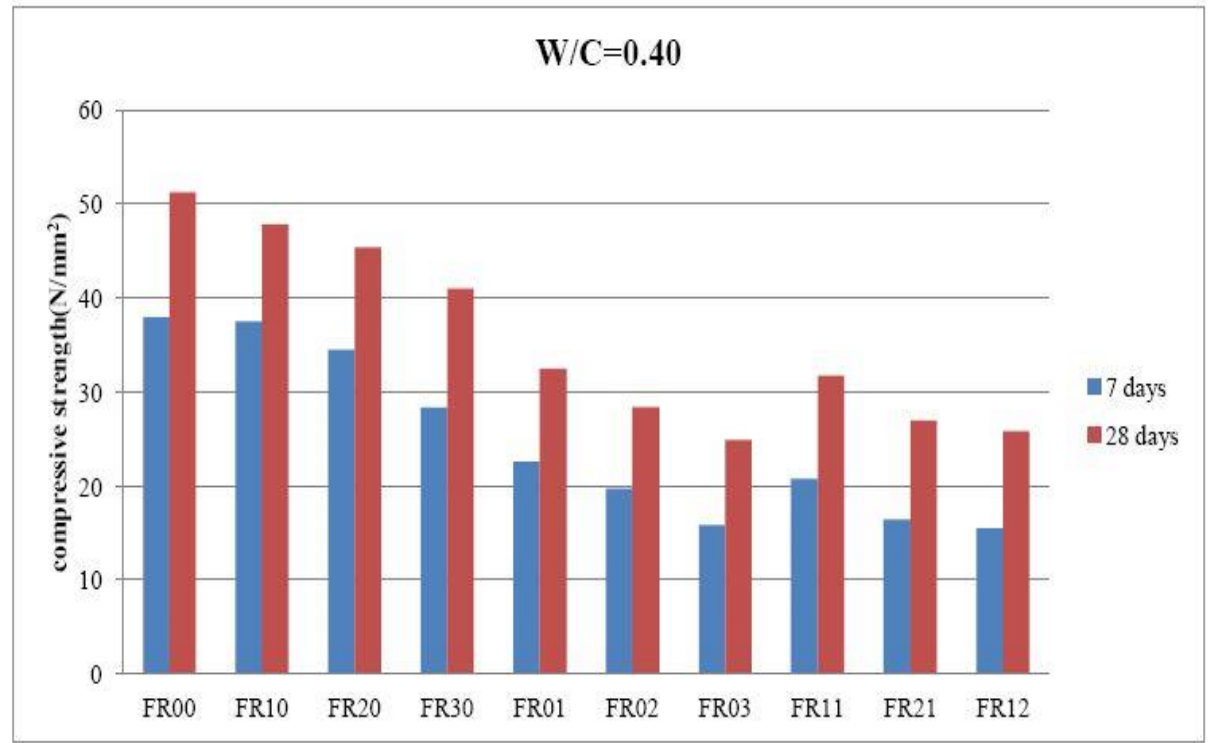

Fig 2.4: 7-day and 28-day compressive strengths with w/c $=0.40$ 


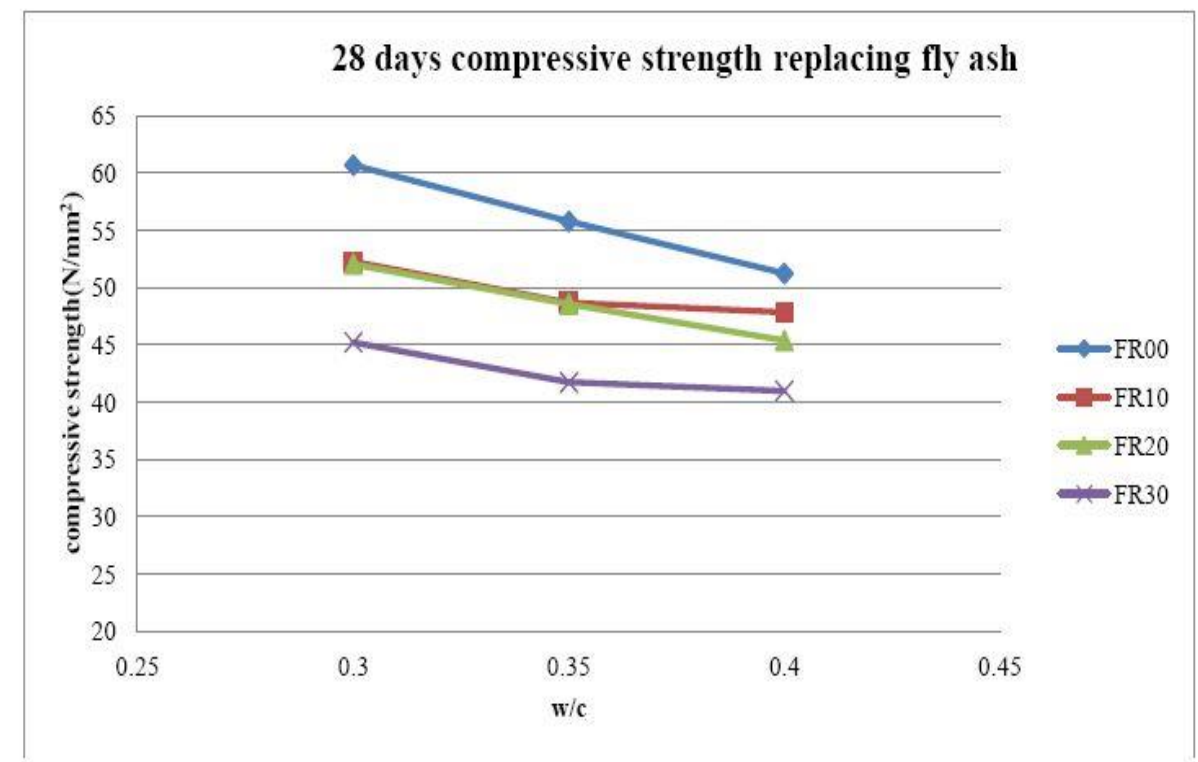

Fig 2.5: 28-day compressive strength replacing Fly ash

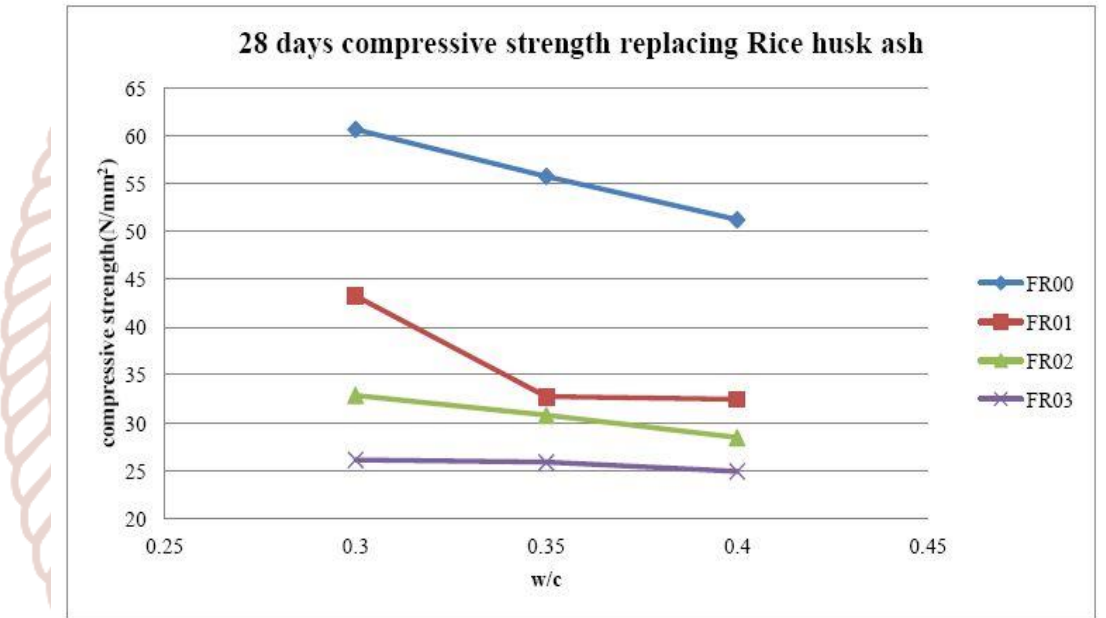

Fig 2.6: 28-day compressive strength replacing Rice husk ash

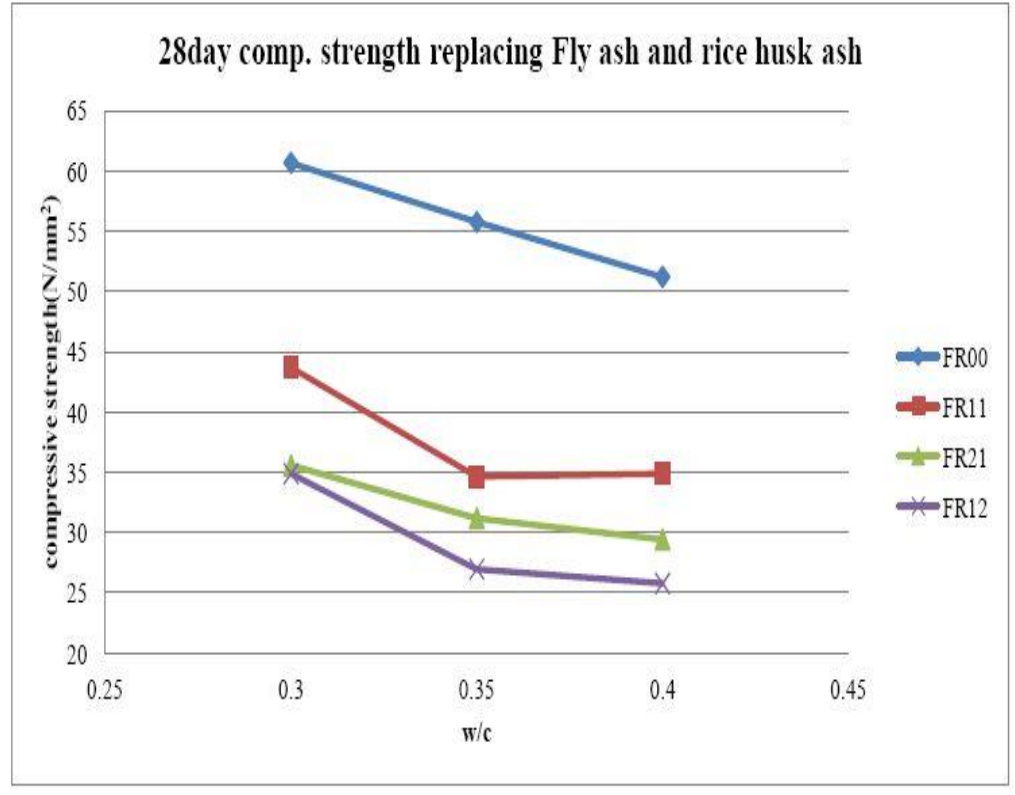

Fig 2.7: 28-day compressive strength replacing fly ash and rice husk ash 


\subsection{Discussion Of Results}

2.2.1 Effect of Fly ash and Rice husk Ash Replacement on Compressive Strength of Concrete a) Effect of age on compressive strength

Fig. 4.1 to 4.7 and Tables 4.1 to 4.3 show the variation of compressive strength of Quality Concrete due to variation in the replacement levels of fly ash and rice husk ash, individually as well as in combinations, at the curing ages of 7 and 28 days.

The Tables 4.7 to 4.9 and Figures 4.12 to 4.14 show the percentage increase in values of compressive strengths with age (from 7 to 28 days) for all the replacement combination concrete mixes with w/c ratios of $0.30,0.35 \& 0.40$ respectively. From the data as presented, it can be seen that the mixes with only fly ash replacement has a lesser rate of increase in strength from 7 days to 28 days though they have high initial strength, than the mixes with rice husk ash replacement only and mixes with both fly ash and rice husk ash as replacement of cement. The mixes with the inclusion of both rice husk ash and fly ash as replacement material show the highest rate of increase of strength for all water to cement ratios indicating that pozzolanic activity initiates early for such mixes.

Table 2.4 - Effect of Age on Compressive Strength of Concrete $\mathrm{W} / \mathrm{C}=\mathbf{0 . 3}$

\begin{tabular}{|c|c|c|c|}
\hline $\mathrm{W} / \mathrm{C}=0.3$ & 7-DAY & 28-DAY & \% INCREASE \\
\hline FR00 & 45.4562 & 60.6778 & 33.486 \\
\hline FR10 & 41.4092 & 52.2374 & 26.149 \\
\hline FR20 & 43.4455 & 52.0518 & 19.809 \\
\hline FR30 & 31.8102 & 45.2104 & 42.125 \\
\hline FR01 & 25.74 & 43.25 & 68.026 \\
\hline FR02 & 22.54 & 32.8583 & 45.778 \\
\hline FR03 & 20.3421 & 26.102 & 28.315 \\
\hline FR11 & 30.87 & 43.7 & 41.561 \\
\hline FR21 & 24.97 & 35.57 & 42.451 \\
\hline FR12 & 21.24 & 34.89 & 64.266 \\
\hline
\end{tabular}

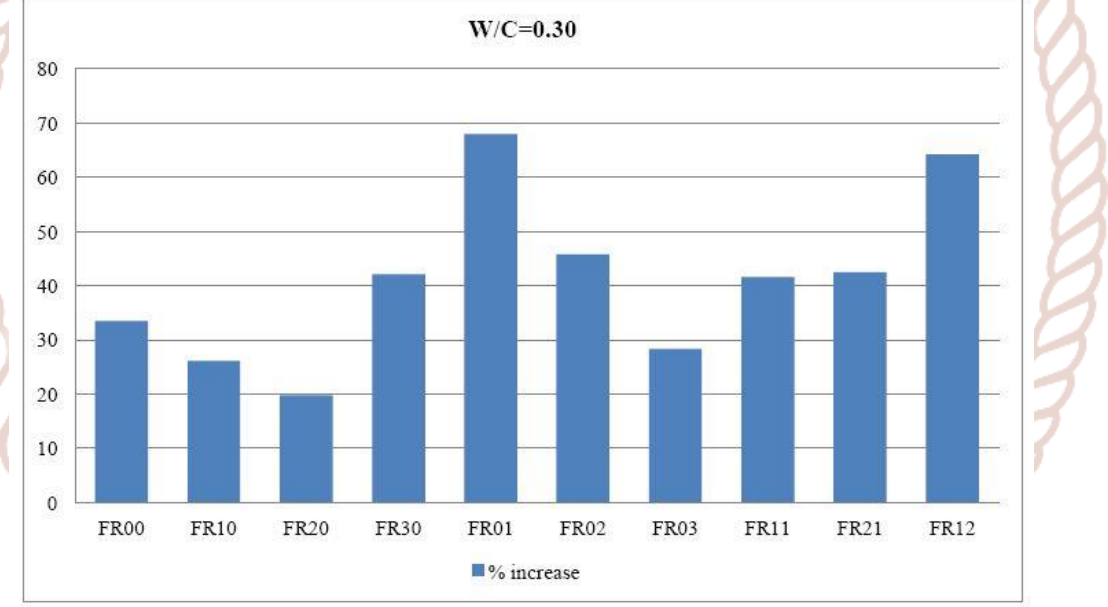

Fig 2.8 Percentage increase in compressive strengths of 7 days to 28 days $\mathrm{W} / \mathrm{C}=0.30$

Table 2.5 - Effect of Age on Compressive Strength of Concrete W/C = 0.35

\begin{tabular}{|c|c|c|c|}
\hline W/C $=\mathbf{0 . 3 5}$ & 7-DAY & 28-DAY & \% INCREASE \\
\hline FR00 & 40.172 & 55.764 & 38.813 \\
\hline FR10 & 37.519 & 48.68 & 29.748 \\
\hline FR20 & 34.175 & 48.548 & 42.057 \\
\hline FR30 & 32.142 & 41.713 & 29.777 \\
\hline FR01 & 24.77 & 32.71 & 32.055 \\
\hline FR02 & 21.547 & 30.762 & 42.767 \\
\hline FR03 & 18.258 & 25.841 & 41.532 \\
\hline FR11 & 22.758 & 34.661 & 52.302 \\
\hline FR21 & 20.1948 & 31.214 & 54.565 \\
\hline FR12 & 17.274 & 29.45 & 70.487 \\
\hline
\end{tabular}




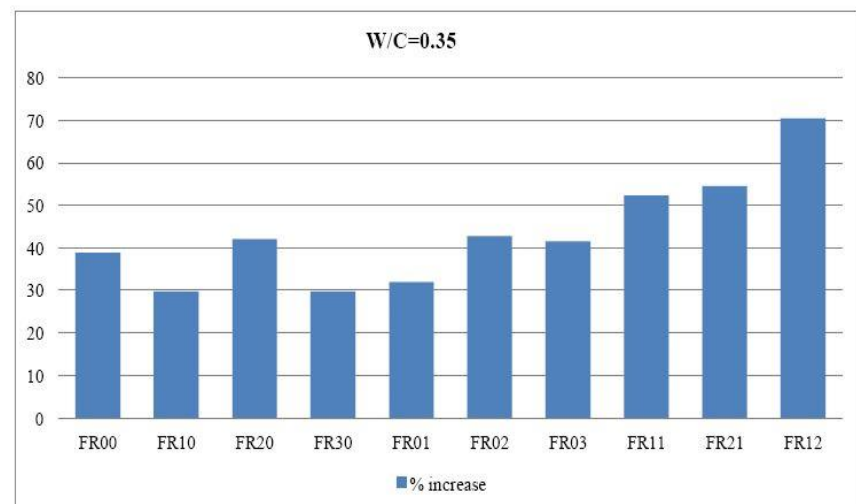

Fig 2.9 Percentage increase in compressive strengths of 7days to 28 days $\mathrm{W} / \mathrm{C}=\mathbf{0 . 3 5}$

Table 2.6 - Effect of Age on Compressive Strength of Concrete $\mathrm{W} / \mathrm{C}=\mathbf{0 . 4 0}$

\begin{tabular}{|c|c|c|c|}
\hline $\mathbf{W} / \mathrm{C}=\mathbf{0 . 4 0}$ & 7-DAY & 28-DAY & \% INCREASE \\
\hline FR00 & 37.92 & 51.22 & 35.074 \\
\hline FR10 & 37.54 & 47.84 & 27.437 \\
\hline FR20 & 34.4524 & 45.36 & 31.660 \\
\hline FR30 & 28.3268 & 40.9826 & 44.678 \\
\hline FR01 & 22.55 & 32.44 & 43.858 \\
\hline FR02 & 19.7522 & 28.4137 & 43.851 \\
\hline FR03 & 15.8511 & 24.8955 & 57.059 \\
\hline FR11 & 20.7667 & 31.7525 & 52.901 \\
\hline FR21 & 16.45 & 26.9688 & 63.944 \\
\hline FR12 & 15.47 & 25.79 & 66.710 \\
\hline
\end{tabular}

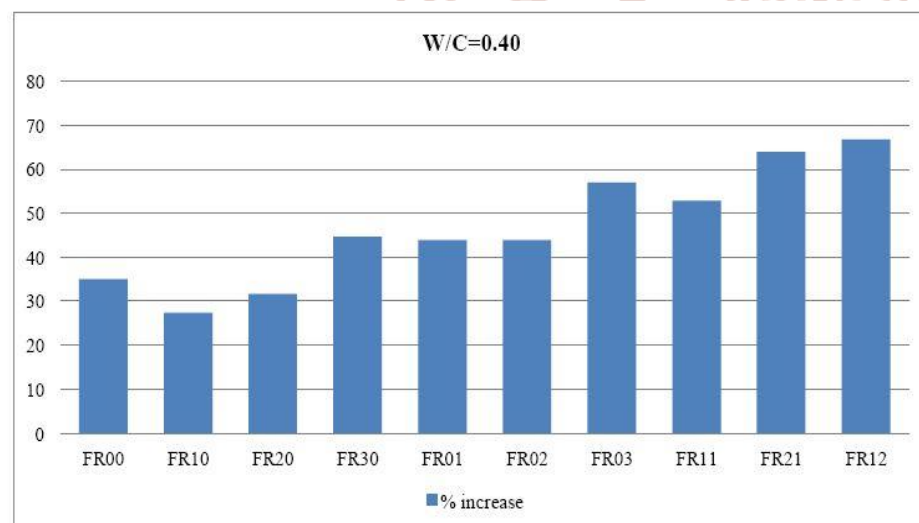

Fig 2.10 Percentage increase in compressive strengths of 7days to 28 days $\mathrm{W} / \mathrm{C}=\mathbf{0 . 4 0}$

b) Effect of replacement levels of mineral admixtures on compressive strength of Concrete The Tables 4.12 to 4.14 and Fig. 4.15 to 4.20 show the percentage variation in compressive strengths of the mixes with fly ash and rice husk ash as replacement materials, individually as well as in combination, as compared to the strength of the control mix specimen and also relative to the minimum required design compressive strength for PQC mixes (as per MoRTH standards the value is $40 \mathrm{MPa}$ ). The variations are shown for all the three water to cement ratios of $0.30,0.35$ and 0.40 . It is observed that for all the water-cement ratios none of the concrete mixes, with partial cement replacement with fly ash and rice husk ash, could achieve the compressive strength value of the control mix in 28 day curing period. The mixes containing only $10 \%$ fly ash could achieve $85 \%$ of the control strength, whereas, the mixes containing only $30 \%$ rice husk as replacement achieved only $45 \%$ of the target controlled strength. When compared with the minimum required design compressive strength for PQC mixes (as per MORTH standards the value is $40 \mathrm{MPa}$ ), it is observed that all the mixes with fly ash replacement showed higher compressive strengths than required for $\mathrm{PQC}$ for all replacement levels and for all water to cement ratios. The concrete mixes with replacement of cement by rice husk ash only, could not achieve the desired PQC strength for water to cement ratios 0.35 and 0.40 , but with $10 \%$ replacement of rice husk ash and combined replacement of $10 \%$ each of fly ash and rice husk ash with a water-cement ratio of 0.3 higher compressive strengths were observed as compared to the minimum required for quality Concrete.

\subsection{CONCLUSIONS}

The study was undertaken to investigate the effect of partial replacement of cement with fly ash and rice husk ash on compressive strength and flexural strength of concrete mix. Cement was partially replaced by fly ash at three different levels of replacement i.e. $10 \%, 20 \%$ and $30 \%$ and same with rice husk ash as well as with combined replacements of fly ash and rice husk ash. Tests were performed after 28 days of curing of concrete. Cubes and beams were prepared for determining compressive strength and flexural strength of concrete with different watercement ratio as 0.30, 0.35 and 0.40 for min required flexural designs 5.5 $\mathrm{MPa}, 5 \mathrm{MPa} \& 4.5 \mathrm{MPa}$ respectively. Super-plasticizer was used in all the mixes at $1 \%$ level by weight of cementations material.

From the experimental results, the conclusions of compressive strength, flexural strength and the pavement quality concrete slab thickness are concluded as under: 


\subsubsection{Workability of concrete}

The amount of SP requirement of mixtures for achieving a desired slump in the range of (80-100 $\mathrm{mm}$ ) is shown in Table 2. To attain the desired slump, the concretes containing RHA required higher water content than those containing only Portland cement. This is due to the high specific surface area and high carbon content of RHA [1, 12]. Therefore, the SP content of RHA concrete mixtures is higher than that of the control mixture. The SP content increases along with the RHA percentage.

\subsubsection{Compressive Strength}

> The mixes with only fly ash replacement has a lesser rate of increase in strength from 7 days to 28 days despite the fact that they have high initial strength, than the mixes with rice husk ash replacement only. The mixes with the inclusion of both rice husk ash and fly ash as replacement material show the highest rate of increase of compressive strength for all water to cement ratios which indicates indicates that pozzolanic activity initiates early for such mixes.

$>$ Concrete mix with up to $20 \%$ percent replacement of cement with fly ash for $0.40 \mathrm{w} / \mathrm{c}$ ratio have higher compressive strengths than minimum required as per MoRT\&H specifications.

$>$ Concrete mixes with replacement of rice husk ash in all water-cement ratios have lesser compressive strengths than minimum required as per MoRT\&H specifications.

> Combined replacement of fly ash and rice husk ash in $\mathrm{w} / \mathrm{c}=0.3 \& 0.35$ showed higher compressive strengths than only replacement of concrete mixes with rice husk ash.

$>$ Concrete mixes with combined replacement of fly ash and rice husk ash in all water-cement ratios have lesser compressive strengths than minimum required as per MoRT\&H specifications.

\section{REFERENCES}

1. [MW 1996] Muhammad Soaib Ismail and A. M. Waliuddin - "Effect of rice husk ash on high strength concrete" Construction and Building Material, Vol. 10. No. 7, 1996, 521-526

2. [RS 2003] Rama Rao G. V. and Sheshagiri Rao M.V. - "High performance Concrete with Rice Husk Ash as Mineral Admixture" ICI Journal, April-June 2003, pp.17-22

3. [BD 2003] Boutterrin C. and Davidovits J. "Geopolymeric cross-linking (LTGS) and building materials" Geopolymer '88 proceedings, 1, 2003, pp 79-88

4. [S 2003] R. Siddique - "Effect of fine aggregate replacement with class $F$ fly ash on the mechanical properties of concrete" Cement and Concrete Research, 2003 vol 4, pp 539-547 [PAA 2004] P. Srinivasan, A. K. Tiwari, Anil Banchhor - "Suitability of HVFA concrete for pavements" Indian Concrete Journal, Vol. 78 (11), November 2004, pp 58-61 [BTN 2007] Binod Kumar, G.K. Tike, P. K. Nanda - "Evaluation of properties of high-volume fly-ash concrete for pavements" Journal of Materials in Civil Engineering, Vol. 19 (10), October 2007: 906-911

5. [C 2007] S. Chalee - "Effect of W/C ratio on covering depth of Fly Ash concrete in marine environment" Cement and Concrete Research, 34 vol 1, 2007, pp. 99-102. [RV 2008] Rangan B. V. "Mix design and production of fly ash based geopolymer concrete" Indian Concrete Journal, 82(5), 2008, pp 7-15 [DMB 2009] M. U Dabai, C. Muhammad, B. U. Bagudo and A. Musa "Studies on the Effect of Rice Husk Ash as Cement Admixture" Nigerian Journal of Basic and Applied Science, 17(2), 2009, 252-256

6. [RMA 2009] A. A. Ramezanianpour, M. Mahdi khani, Gh. Ahmadibeni - "The Effect of Rice Husk Ash on Mechanical Properties and Durability of Sustainable Concretes" 7(2), 2009, pp 83-91

7. [U 2010] U. Duweriya - "Investigation of Compressive Strength of Concrete Containing Rice-Husk-Ash" International Conference on Sustainable Built Environment (ICSBE-2010) Kandy, pp. 13-14

8. [CM 2010] P. Chandan Kumar, P. Malleswara Rao - "Benefits of use of Rice Husk Ash in Concrete" Jr. of Industrial Pollution Control 26 vol. 2 EM International, 2010, pp 239-241

9. [JMI 2010] Jayasankar R, Mahindran. N, Ilangovan. R, - "Concrete using Fly Ash, Rice Husk Ash and Egg Shell Powder", International journal of civil and structural engineering, Volume 1, No 3, 2010

10. [CM 2012] C. Marthong - "Effect of Rice Husk Ash (RHA) as Partial Replacement of Cement on Concrete Properties" International Journal of Engineering Research \& Technology (IJERT), 1(6), 2012, pp 1-7 
International Journal of Trend in Scientific Research and Development (IJTSRD) ISSN: 2456-6470

11. [MC 2012] Marthong C - "Effect of Rice Husk Ash (RHA) as Partial Replacement of Cement on Concrete Properties" International Journal of Engineering Research \& Technology (IJERT) ISSN: 2278-0181, Vol. 1 Issue 6, August - 2012
12. [DSN 2012] R. S. Deotale, S. H. Sathawane, A. R. Narde - "Effect of Partial Replacement of Cement by Fly Ash, Rice Husk Ash with Using Steel Fiber in Concrete" International Journal of Scientific \& Engineering Research, ISSN 2229-5518 Volume 3, Issue 6, June-2012

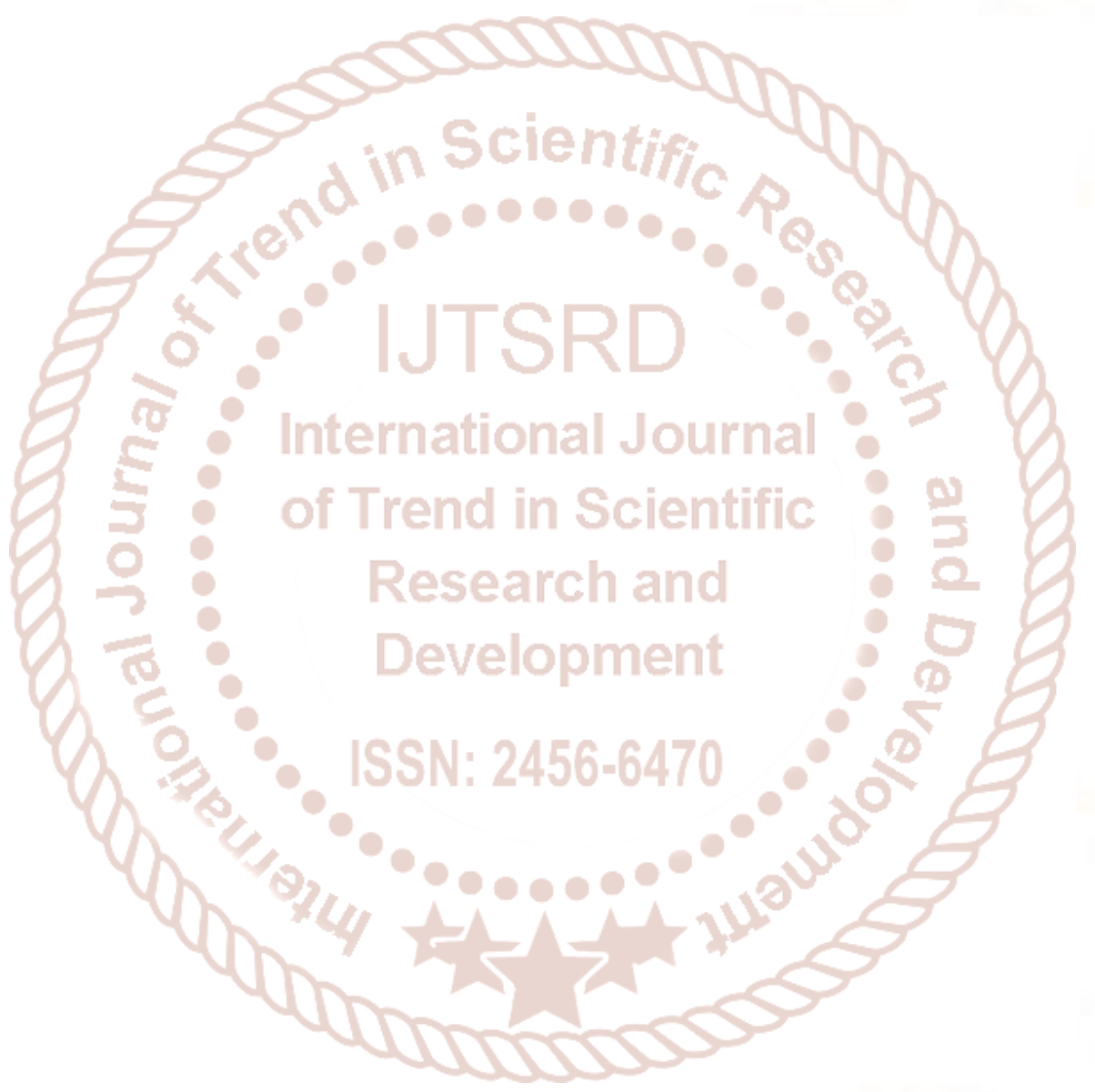

